\title{
Development of industrial waste disposal scenarios using life-cycle assessment approach
}

\author{
J. Nouri $\cdot$ N. Nouri $\cdot$ M. Moeeni
}

Received: 12 March 2012 / Accepted: 2 May 2012/Published online: 25 May 2012

(C) CEERS, IAU 2012

\begin{abstract}
In this study, environmental impacts of industrial waste disposal of used lubricating oils and sulphur wastes scenarios have been investigated and modeled. The life-cycle assessment methodology was selected among the environmental impact assessment methods. In this method environmental issues and burdens were quantitated in order to facilitate the comparison. In this regard, options with the least adverse impacts were suggested. Functional unit of the study has also been defined as amount of used lubricating oils and sulphur wastes in terms of kilograms based on capacity of transitional barrel. Accordingly, the system boundaries were selected for life cycle of the wastes produced in sulphur unit of Tehran Oil Refinery. Since the main disposal method applied in Tehran Oil Refinery was transference to the municipal landfill, two incineration and landfilling scenarios were modeled for used lubricating oils and sulphur wastes by means of Simapro-7.1 software. Then, the outputs of these scenarios were compared in terms of the least environmental impacts by EDIP 2003 and Ecoindicator 99 methods. Finally, incineration scenarios were recommended as the most efficient ones.
\end{abstract}

Keywords Industrial waste - Life-cycle assessment . Oil refinery $\cdot$ Sulphur solid waste $\cdot$ Used lubricating oil disposal

\section{J. Nouri · M. Moeeni ( $\square)$}

Department of Environmental Management,

Science and Research Branch, Islamic Azad University, Tehran, Iran

e-mail: moeeni.mina@gmail.com

\section{N. Nouri}

Doctoral Program in Environmental Management, Earth and Environmental Studies, Montclair State University, Montclair, NJ 07043, USA

\section{Introduction}

As environmental awareness increases, industries and businesses become obsessed in assessing how their activities affect the environment. The society has become concerned about natural resource depletion and environmental degradation issues (Curran 2006; Chen et al. 2010; Tehrani et al. 2010). The oil is used in our everyday lives and unlike hydrogen or even natural gas it is easily transportable and has a vast infrastructure in place for its use to be supported. Though the supplied oil and energy provide multiple benefits to human society, every stage in the life cycle from exploration to use can have harmful effects on our health and the environment (Epstein and Slber 2002). Modern oil refining essentially involves two categories of processing: the physical separation of the raw material into a range of homogeneous petroleum fractions and the subsequent chemical conversion of certain fractions to alter the product yield and improve product quality. Physical processes include distillation (the extraction of the volatile components of a mixture by the condensation and collection of the vapors that are produced as the mixture is heated) and blending (to combine or mix so that the constituent parts are indistinguishable from one another) and chemical processes include cracking (the process whereby complex organic molecules such as kerogens or heavy hydrocarbons are broken down into simpler molecules), coking (a carbonaceous solid derived from oil refinery coker units or other cracking processes), reforming (a chemical process used to convert petroleum refinery naphthas, typically having low octane ratings, into highoctane liquid products), alkylation (transfer of an alkyl group from one molecule to another), polymerization (in the polymerization, one carbon-carbon double bond (in the vinyl group) is replaced by a much stronger carbon-carbon 
single bond), isomerization (the conversion of a compound into an isomer of itself) and hydrogen treatment (which involves removing hydrogen from hydrocarbons producing compounds with higher octane ratings such as aromatics) (DOE 1995). Prevention or reduction of waste production and its harmfulness may be possible in particular by development of clean technologies that use fewer natural resources. Technical development and marketing of products use final disposal decrease the amount or harmfulness of waste and pollution hazards. The recovery of waste by means of recycling, reuse or reclamation or any other processes with respect to interacting secondary raw materials (that used before but are capable for reuse), or use of waste as a source of energy is of great significance (Dando and Martin 2003).

In many countries both energy and waste management systems are under change. The changes are largely driven by environmental considerations and the major driving force is the threat of global climate change and the others such as ozone depletion, acidification, toxicity, resource use, and depletion. When making new strategic decisions related to energy and waste management systems, it is therefore of importance to consider the environmental implications. A waste management hierarchy is often suggested and used in waste policy making (Finnveden et al. 2000). Waste management is a complex process because it involves different principles and processes. These include activities and technologies related to manufacturing, maintenance, storage, collection, transfer, transport, processing, and disposal of wastes (Nouri et al. 2011). All these processes should follow the existing social and legal principals, protect the public health and the environment, and be acceptable in terms of beauty and economic aspects (Monavari 2009; Zaman 2010). Wastes generated from oil and gas industrial activities are very diverse in their characteristics, large in their amounts as many of which are hazardous in nature (Elshorbagy and Alkamali 2005). Environmental problems in oil and gas industries are influenced by incorrect decisions. To achieve a sustainable development, new management strategies should be adopted, whereby waste management systems should be evaluated (ISO 14042 2000). Life-cycle assessment (LCA) is best defined as an objective process to evaluate the environmental burdens associated with product and process or activity by identifying and quantifying energy and materials used, and waste released to the environment. Life-cycle assessment evaluates and implements opportunities to allow environmental improvements. In other words, LCA takes into account the issues not addressed by other environmental management tools such as environmental performance evaluation, environmental auditing, material, energy and toxic-analysis, etc. (Al-Salem 2009). Unlike other methods of pollution control which put emphasized on one of the mentioned issues, such as recovery and toxicity reduction, LCA can consider a group of parameters (ISO 14041 1998). The first life cycle analysis was conducted in 1969 on beverage containers. The major objective of the analysis was to determine which type of container had the least effect on natural resources and the environment. The obtained result was identification of energy and material flows, without determining the environmental impact (Levan 2007; Guinee 2011). In the study of MSW management in Phuket, a province in Thailand, two methods were used for landfilling (without energy recovery) and incineration (with energy recovery), were compared from both energy consumption and greenhouse gas emission points of view (Liamsanguan and Gheewala 2007). In another study aiming at evaluation of the environmental implications of fermentable fraction of waste management in Barcelona metropolitan area (BMA), LCA was performed comparing the present management system with the system proposed for the future (Guereca et al. 2006). In a study on global environmental analysis of waste water treatment and some possible additional tertiary treatments allowing water reuse to that purified waters, LCA was implemented to establish a technology with a broad perspective and in a rigorous and objective way in order to provoke the lowest environmental load (Ortiz et al. 2006). In this study, the environmental impacts of industrial waste disposal types, sulphur waste, and used oil scenarios have been investigated and modeled. Using a real problem at an oil refinery as a case study, the approaches have been developed in greater depth with application of LCA shown to aid the generation of alternatives and to provide the decision maker with valuable insights (White et al. 2011). The LCA methodology was selected among the environmental impact assessment methods, such as economic input-output assessment, risk assessment, strategic impact assessment, etc. In this method environmental issues and burdens were quantitated in order to facilitate the comparison. Ultimately, the options with the least adverse impacts were suggested. This research has been carried out in connection with LCA of used lubricating oils and sulphur wastes disposal in Tehran oil refinery in Tehran, Iran, in 2011.

\section{Materials and methods}

The working method for LCA is structured along with a framework that has become the subject of world-wide consensus which forms the basis of a number of ISO standards. This framework divides the entire LCA procedure into four distinct phases as goal and scope definition, inventory analysis, impact assessment, and interpretation (Guinee 2002). The description of each phase is presented in Fig. 1. 


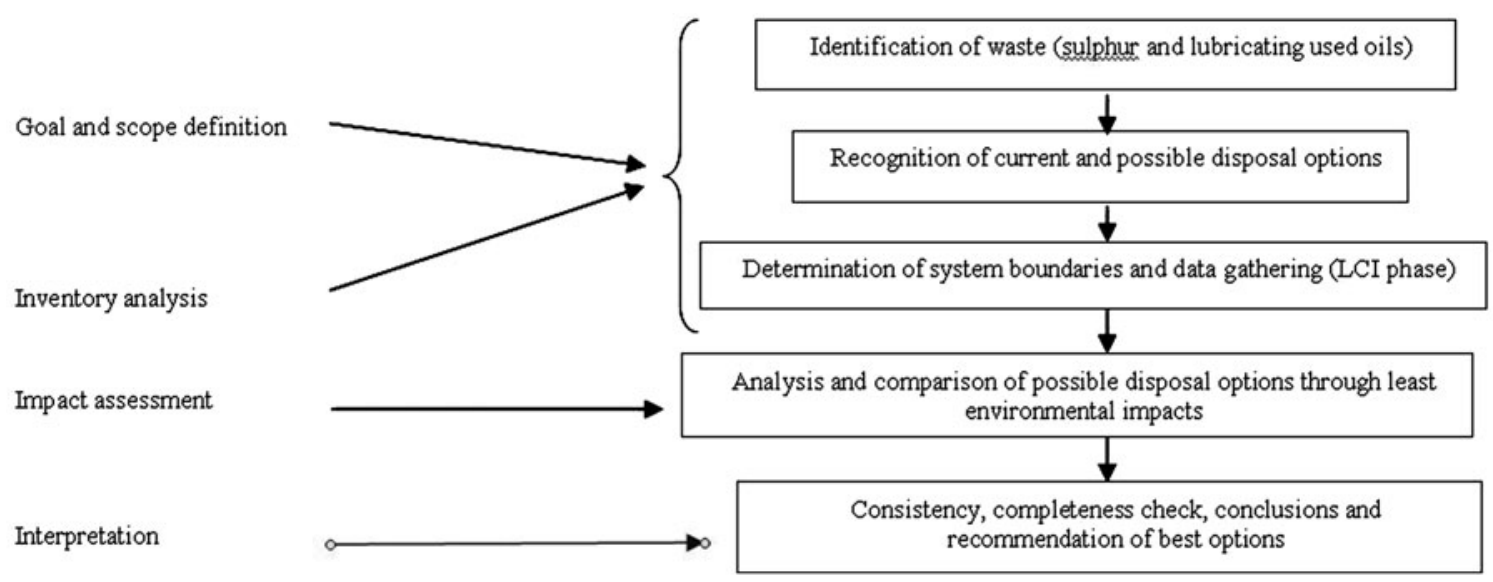

Fig. 1 Flow chart and step-by-step procedure involved in this paper

Table 1 The amounts and characteristics of Tehran Oil Refinery wastes (Tehran Oil Refinery 2011)

\begin{tabular}{|c|c|c|c|c|c|c|c|c|c|}
\hline Name & $\begin{array}{l}\text { Material } \\
\text { phase }\end{array}$ & $\begin{array}{l}\text { Waste } \\
\text { group }\end{array}$ & $\begin{array}{l}\text { Type/ } \\
\text { combination }\end{array}$ & Location & $\begin{array}{l}\text { Status/ } \\
\text { condition }\end{array}$ & Amount/value & $\begin{array}{l}\text { Discharge } \\
\text { frequency }\end{array}$ & $\begin{array}{l}\text { Collection } \\
\text { equipment }\end{array}$ & $\begin{array}{l}\text { Current disposal } \\
\text { method }\end{array}$ \\
\hline Sulphur & Solid & Industrial & Sulphur & $\begin{array}{l}\text { Sulphur } \\
\text { unit }\end{array}$ & Normal & $\begin{array}{l}10 \mathrm{barrel} / \\
2,000 \mathrm{~kg}\end{array}$ & Monthly & Barrel & $\begin{array}{l}\text { Transferred to the } \\
\text { municipal landfill }\end{array}$ \\
\hline $\begin{array}{c}\text { Used } \\
\text { oil }\end{array}$ & Liquid & Industrial & Oil & $\begin{array}{l}\text { Sulphur } \\
\text { unit }\end{array}$ & Normal & $\begin{array}{l}5 \text { barrel } / 1,100 \\
\mathrm{~L} / 880 \mathrm{~kg}\end{array}$ & Monthly & Barrel & $\begin{array}{l}\text { Transferred to the } \\
\text { municipal landfill }\end{array}$ \\
\hline
\end{tabular}

From Fig. 1, it may be inferred that in the goal and scope definition phase, two different scenarios of used lubricating oils and sulphur wastes were developed, and then compared by EDIP-2003 and Ecoindicator-99 methods with respect to their environmental burdens. The functional unit in this study has been defined as the amount of used lubricating oils and sulphur wastes in terms of kilograms. The system boundaries selected for the life cycle of the wastes produced in sulphur unit of Tehran Oil Refinery. In the life cycle inventory phase, the data were secured mainly from field visits of the oil refinery and database of Simapro-7.1 software and the handbook on LCA, an operational guide to the ISO standards. Table 1 shows the characteristics and amounts of two wastes.

From Table 1, it can be observed that the selected sulphur waste is identified as solid waste and lubricating oils are identified as liquid waste.

Life-cycle impact assessment is defined as a phase in the LCA aimed at understanding and evaluating the magnitude and significance of the potential environmental impacts of a product system (Goedkoop et al. 2008). Since the main disposal method applied in Tehran Oil Refinery was transference to the municipal landfill with $13,000,000 \mathrm{~m}^{2}$ areas without surface and groundwater drainage and trench method, two incineration and landfilling scenarios were modeled for used lubricating oils and sulphur wastes by means of Simapro-7.1 software. In the impact assessment phases, Simapro-7.1 comes with a large number of standard impact assessment methods. Each method contains a number (typically 10 to 20) of impact categories. Further, the selected scenarios were compared in terms of the least environmental impacts by EDIP-2003 and Ecoindicator-99 impact assessment methods. In the interpretation phase, the main elements were evaluated in terms of soundness and robustness, and overall conclusions were presented.

\section{Results and discussion}

Table 2 shows the results of modeled landfill scenario of used lubricating oils by Ecoindicator-99 method.

According to Table 2, through impact assessment of landfilling scenario of used lubricating oils by Ecoindicator-99 method, it was determined that the highest impact was related to the ecotoxicity $(86.5 \%)$ and then carcinogen category $(75 \%)$. Considering the same scenario by EDIP2003 method, it was determined that the highest impacts were related to ecotoxicity water acute $(94 \%)$ and chronic $(81 \%)$, bulk waste $(93 \%)$, human toxicity water $(92 \%)$, and slag/ashes $(81 \%)$ categories.

On the other hand, incineration scenario of the used lubricating oils has been modeled. Table 3 shows the modeled incineration scenario of used lubricating oils by two methods. In considering incineration scenario of used lubricating oils by Ecoindicator-99 method, the highest impacts have been owned by ecotoxicity category ( $84 \%)$, 
Table 2 Landfilling scenario for used oils by two methods (EDIP-2003 and Ecoindicator-99)

\begin{tabular}{|c|c|c|c|}
\hline Category-EDIP 2003 & $(\%)$ & Category-Ecoindicator 99 & $(\%)$ \\
\hline Global warming 100a & 29 & Carcinogens & 75 \\
\hline Ozone depletion & 0 & Resp. organics & 2 \\
\hline Ozone formation (vegetation) & 34 & Resp. inorganics & 3 \\
\hline Ozone formation (human) & 35 & Climate change & 28 \\
\hline Acidification & 2 & Radiation & 3.5 \\
\hline Terrestrial eutrophication & 4 & Ozone layer & 0 \\
\hline Aquatic eutrophication $\mathrm{EP}(\mathrm{N})$ & 55.5 & Ecotoxicity & 86.5 \\
\hline Aquatic eutrophication $\mathrm{EP}(\mathrm{P})$ & 3 & Acidification/Eutrophication & 3 \\
\hline Human toxicity (air) & 54 & Land use & 4 \\
\hline Human toxicity (water) & 92 & Minerals & 1 \\
\hline Human toxicity (soil) & 23 & Fossil fuels & 0 \\
\hline Ecotoxicity water (chronic) & 81 & Average & 18.7 \\
\hline Ecotoxicity water (acute) & 94 & & \\
\hline Ecotoxicity soil (chronic) & 5 & & \\
\hline Hazardous waste & 2 & & \\
\hline Slags/ashes & 81 & & \\
\hline Bulk waste & 93 & & \\
\hline Radioactive waste & 3 & & \\
\hline Resources(all) & 5 & & \\
\hline Average & 36.4 & & \\
\hline
\end{tabular}

Table 3 Incineration scenario for used oils by two methods (EDIP-2003 and Ecoindicator-99)

\begin{tabular}{|c|c|c|c|}
\hline Category-EDIP 2003 & $(\%)$ & Category-Ecoindicator 99 & $(\%)$ \\
\hline Global warming $100 \mathrm{a}$ & 31 & Carcinogens & 20 \\
\hline Ozone depletion & 0 & Resp. organics & 0.5 \\
\hline Ozone formation (vegetation) & 6 & Resp. inorganics & 6 \\
\hline Ozone formation (human) & 5 & Climate change & 32 \\
\hline Acidification & 4 & Radiation & 3 \\
\hline Terrestrial eutrophication & 15 & Ozone layer & 0 \\
\hline Aquatic eutrophication $\mathrm{EP}(\mathrm{N})$ & 18 & Ecotoxicity & 84 \\
\hline Aquatic eutrophication $\mathrm{EP}(\mathrm{P})$ & 10 & Acidification/eutrophication & 11 \\
\hline Human toxicity (air) & 6 & Land use & 0.5 \\
\hline Human toxicity (water) & 82 & Minerals & 2 \\
\hline Human toxicity (soil) & 9 & Fossil fuels & 0 \\
\hline Ecotoxicity water (chronic) & 81 & Average & 14.4 \\
\hline Ecotoxicity water (acute) & 89 & & \\
\hline Ecotoxicity soil (chronic) & 6 & & \\
\hline Hazardous waste & 5 & & \\
\hline Slags/ashes & 100 & & \\
\hline Bulk waste & 30 & & \\
\hline Radioactive waste & 3 & & \\
\hline Resources(all) & 2.5 & & \\
\hline Average & 26.4 & & \\
\hline
\end{tabular}

then climate change (32\%) and carcinogen categories (20\%). In EDIP-2003 method, the highest impacts have been owned by slag/ashes (100\%), ecotoxicity water acute
(89 \%), ecotoxicity water chronic (81\%), human toxicitywater $(82 \%)$ categories, and middle impacts belonged to global warming $(31 \%)$ and bulk waste $(30 \%)$ categories. 
Table 4 Incineration scenario for used oils by two methods (EDIP-2003 and Ecoindicator-99)

\begin{tabular}{|c|c|c|c|}
\hline Category-EDIP 2003 & $(\%)$ & Category-Ecoindicator 99 & $(\%)$ \\
\hline Global warming $100 \mathrm{a}$ & 45 & Carcinogens & 98 \\
\hline Ozone depletion & 15 & Resp. organics & 25 \\
\hline Ozone formation (vegetation) & 72 & Resp. inorganics & 9 \\
\hline Ozone formation (human) & 73 & Climate change & 44 \\
\hline Acidification & 7 & Radiation & 31 \\
\hline Terrestrial eutrophication & 11 & Ozone layer & 15 \\
\hline Aquatic eutrophication $\mathrm{EP}(\mathrm{N})$ & 79 & Ecotoxicity & 98 \\
\hline Aquatic eutrophication EP(P) & 90 & Acidification/eutrophication & 8 \\
\hline Human toxicity (air) & 85 & Land use & 94 \\
\hline Human toxicity (water) & 99.5 & Minerals & 75 \\
\hline Human toxicity (soil) & 60 & Fosil fuels & 1 \\
\hline Ecotoxicity water (chronic) & 99 & Average & 45.3 \\
\hline Ecotoxicity water (acute) & 99.5 & & \\
\hline Ecotoxicity soil (chronic) & 15 & & \\
\hline Hazardous waste & 100 & & \\
\hline Slags/ashes & 98 & & \\
\hline Bulk waste & 83 & & \\
\hline Radioactive waste & 35 & & \\
\hline Resources(all) & 7 & & \\
\hline Average & 61.7 & & \\
\hline
\end{tabular}

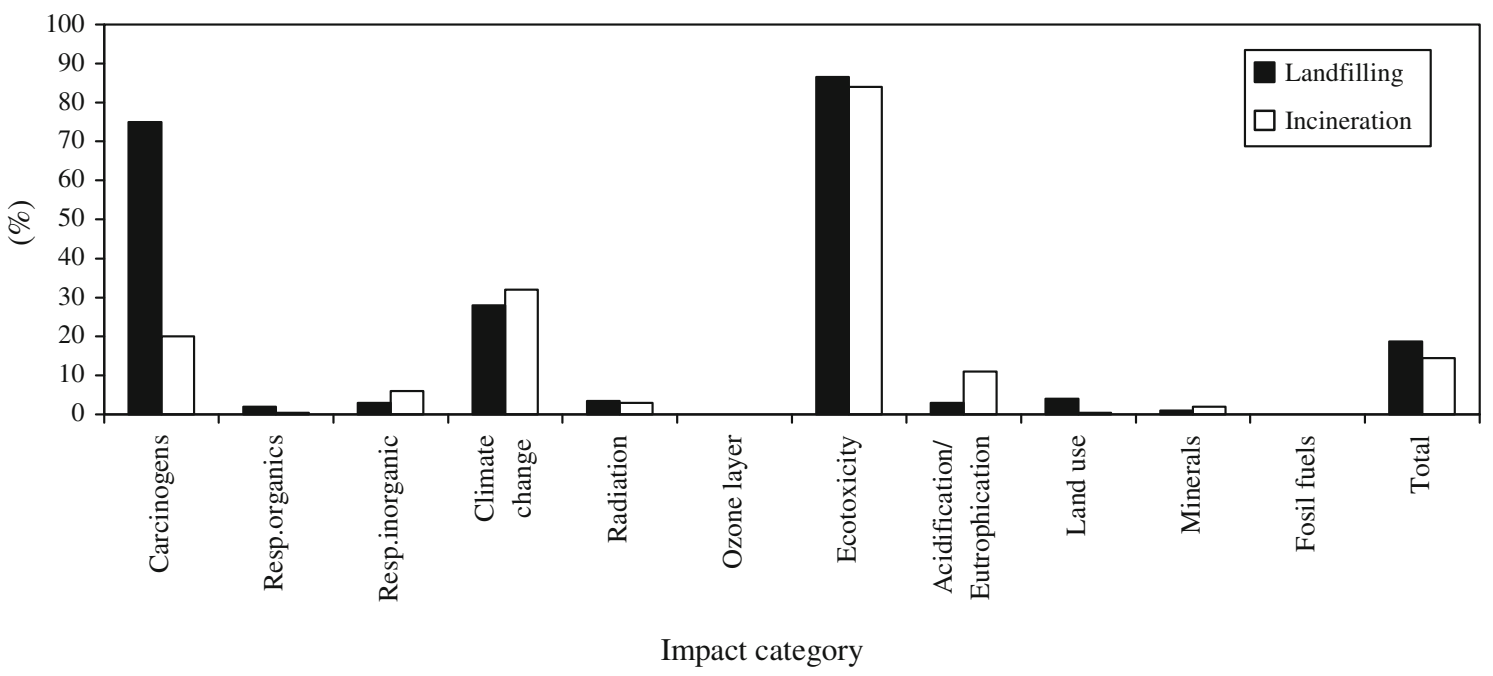

Fig. 2 Comparing landfilling and incineration scenarios of used oil method: Ecoindicator-99 (Simapro-7.1, 2011)

The same scenarios have been modeled and considered for sulphur wastes as indicated in Table 4. Considering the landfilling scenario of sulphur wastes developed by Ecoindicator-99 method (Table 4), it was determined that the highest impacts belonged to ecotoxicity and carcinogen $(98 \%)$, land use $(94 \%)$, mineral $(74 \%)$ categories then climate change $(44 \%)$ and radiation $(31 \%)$ categories. According to the results shown in Table 4, using EDIP2003 method, majority of categories have been involved and the highest impacts possessed by hazardous waste $(100 \%)$, ecotoxicity water acute (99.5), chronic (99\%), human toxicity water $(99.5 \%)$, air $(85 \%)$ and soil $(60 \%)$, aquatic eutrophication (90\%) and ozone formation (70 \%).

Finally the incineration scenario developed by two methods was modeled, and is presented in Figs. 2 and 3. Using the Ecoindicator-99 method (Table 5), the highest impact belonged to ecotoxicity (97\%), minerals (84\%), carcinogens $(80 \%)$, and land use $(79 \%)$ categories. In 


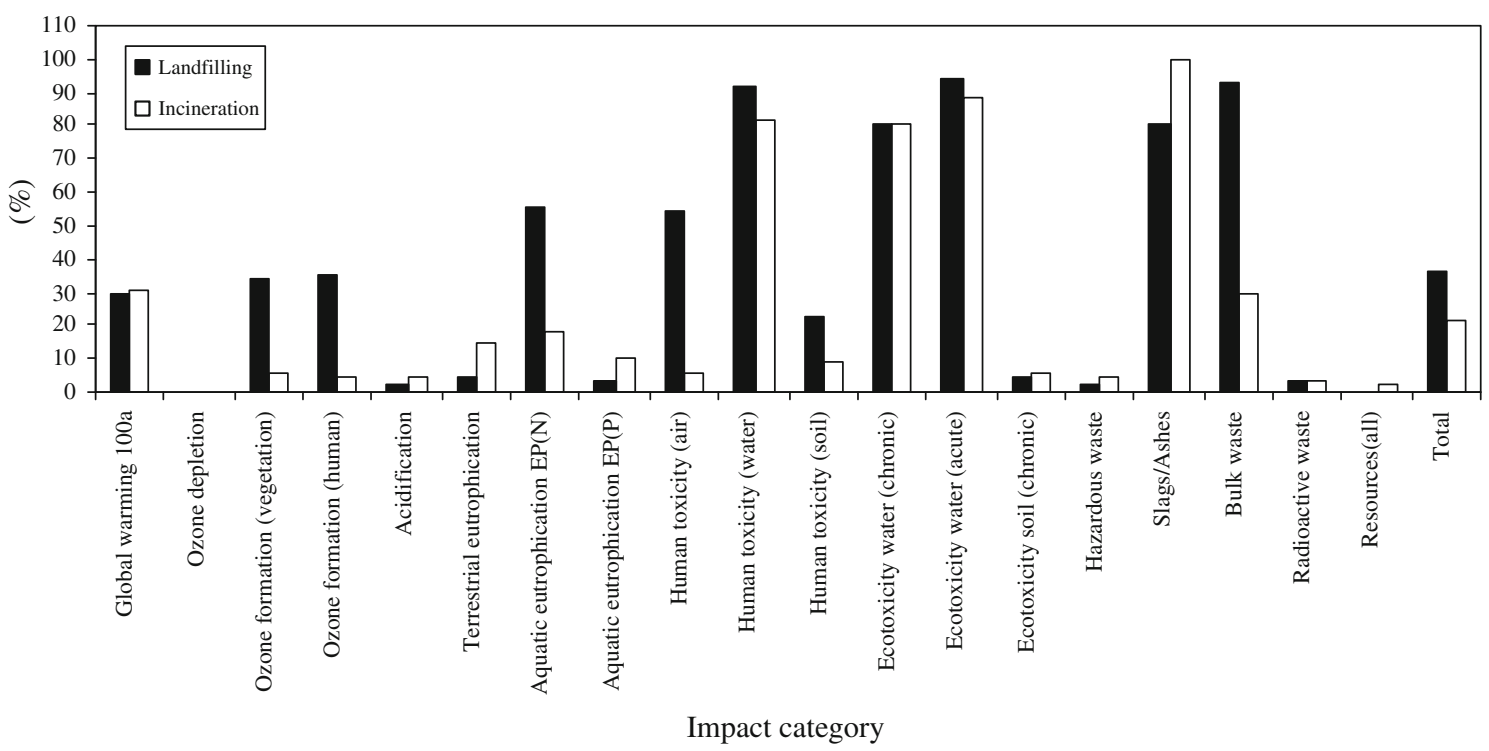

Fig. 3 Comparing landfilling and incineration scenarios of used oil method: EDIP-2003 (Simapro-7.1, 2011)

Table 5 Incineration scenario for used oils by two methods (EDIP-2003; Ecoindicator-99)

\begin{tabular}{|c|c|c|c|}
\hline Category-EDIP 2003 & $(\%)$ & Category-Ecoindicator 99 & $(\%)$ \\
\hline Global warming 100a & 48 & Carcinogens & 80 \\
\hline Ozone depletion & 13 & Resp. organics & 10 \\
\hline Ozone formation (vegetation) & 24 & Resp. inorganics & 19 \\
\hline Ozone formation (human) & 22 & Climate change & 48 \\
\hline Acidification & 10 & Radiation & 26 \\
\hline Terrestrial eutrophication & 35 & Ozone layer & 13 \\
\hline Aquatic eutrophication $\mathrm{EP}(\mathrm{N})$ & 40 & Ecotoxicity & 97 \\
\hline Aquatic eutrophication $\mathrm{EP}(\mathrm{P})$ & 96 & Acidification/eutrophication & 27 \\
\hline Human toxicity (air) & 23 & Land use & 79 \\
\hline Human toxicity (water) & 99 & Minerals & 84 \\
\hline Human toxicity (soil) & 34 & Fosil fuels & 0.5 \\
\hline Ecotoxicity water (chronic) & 98.5 & Average & 44 \\
\hline Ecotoxicity water (acute) & 99.5 & & \\
\hline Ecotoxicity soil (chronic) & 18 & & \\
\hline Hazardous waste & 100 & & \\
\hline Slags/ashes & 100 & & \\
\hline Bulk waste & 14 & & \\
\hline Radioactive waste & 30 & & \\
\hline Resources(all) & 13 & & \\
\hline Average & 48.3 & & \\
\hline
\end{tabular}

Table 5, incineration scenario of sulphur wastes developed by EDIP-2003 method has been considered. The highest impacts were owned by hazardous waste and slag/ashes $(100 \%)$, ecotoxicity chronic and acute (99\%), human toxicity water (99\%) and aquatic eutrophication (96\%). Taking into account the two incineration and landfilling scenarios using Ecoindicator-99 method (Fig. 2), it was determined that the incineration scenario was superior to landfilling scenario, since the average impact of landfilling was $18.7 \%$ while that of incineration was $14 \%$. The obtained results were verified by the EDIP-2003 method as average impact of the landfilling scenario was $36.4 \%$ while that of the incineration scenario was $26 \%$ (Fig. 3).

Referring to Fig. 4, for elaborating on sulphur wastes by Ecoindicator-99 method, it was determined that landfilling scenario accounted for creation of impact of about $45.3 \%$, 


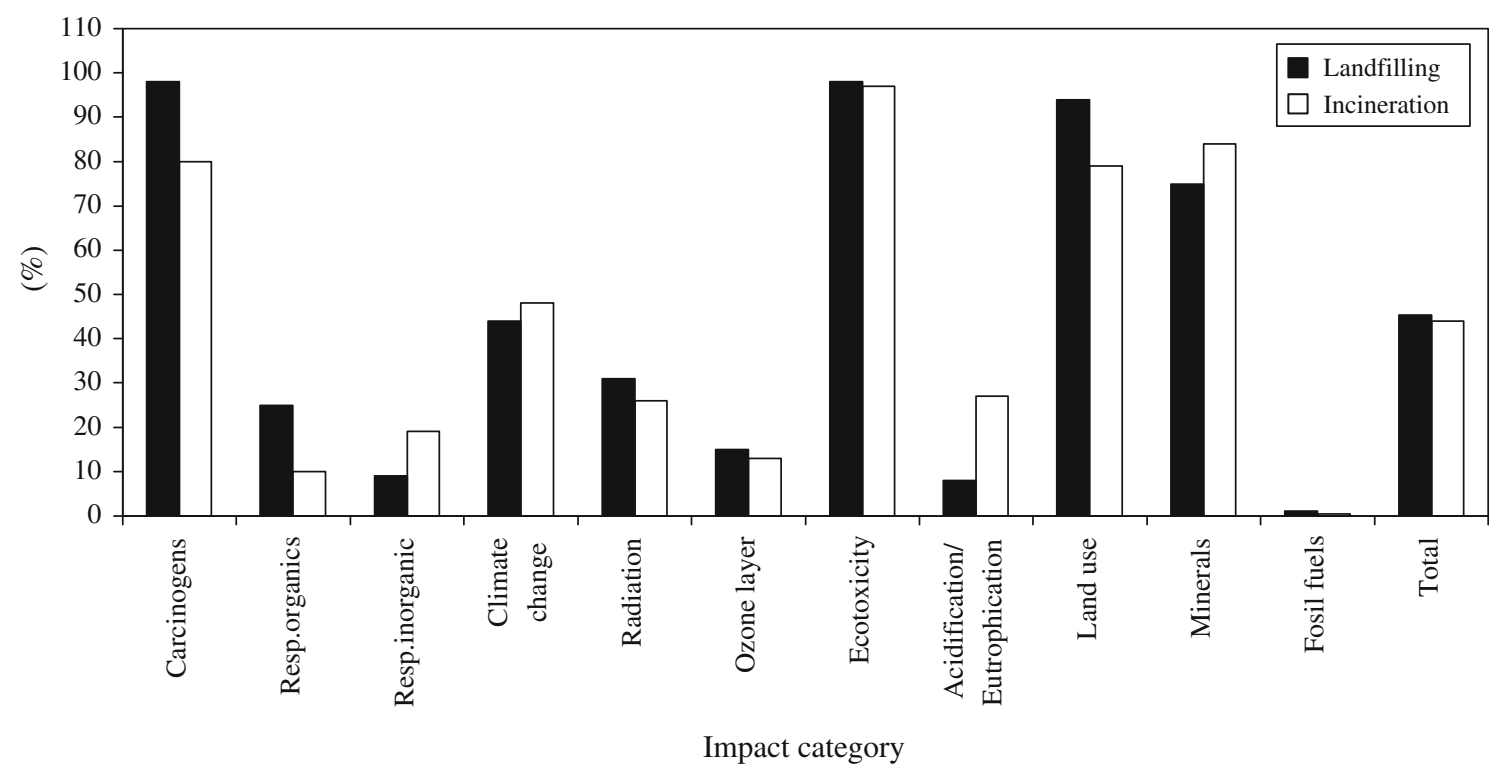

Fig. 4 Comparing landfilling and incineration scenarios of sulphur waste method: Ecoindicator-99 (Simapro-7.1, 2011)

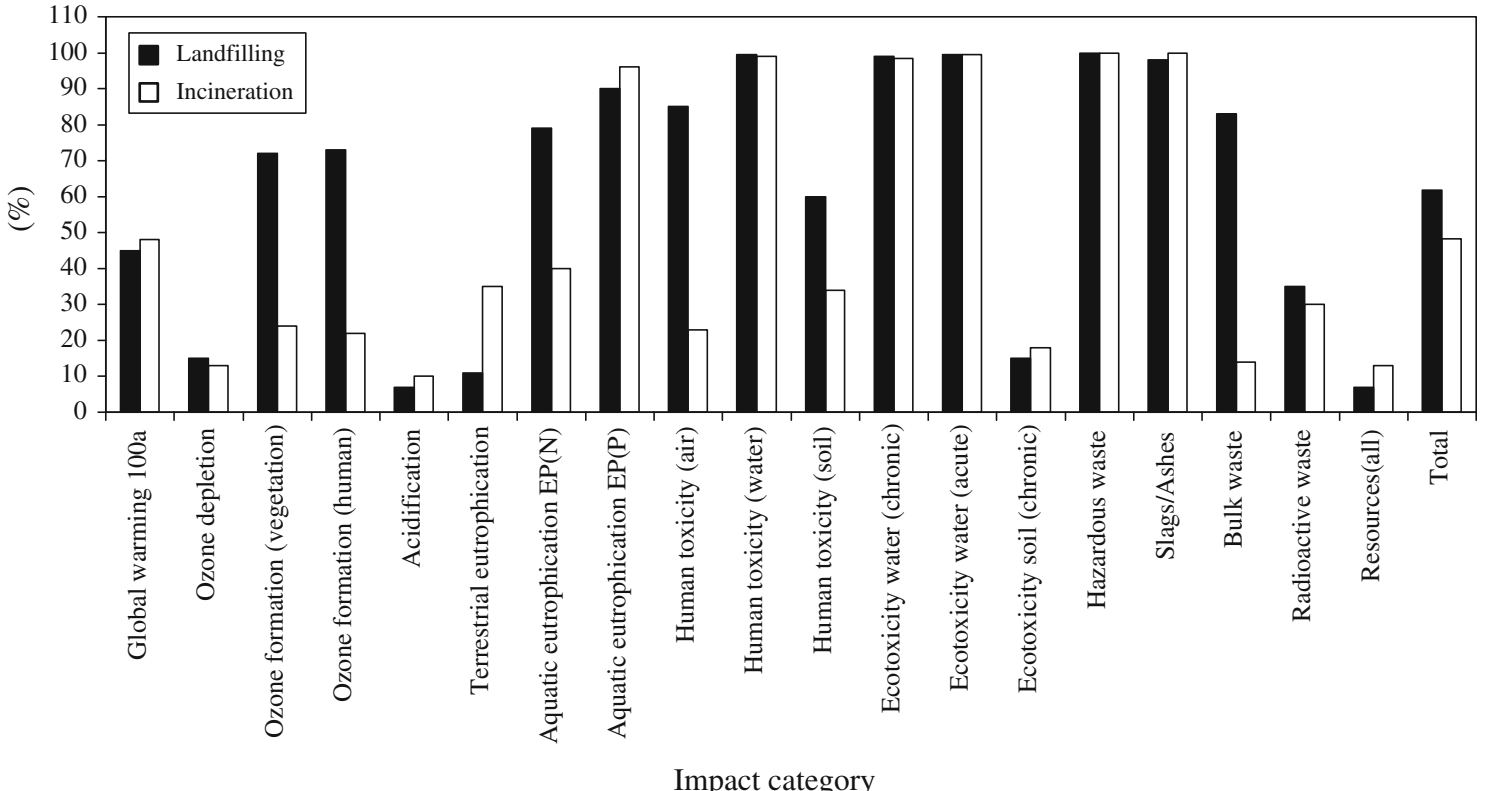

Fig. 5 Comparing landfilling and incineration scenarios of sulphur waste method: EDIP-2003 (Simapro-7.1, 2011)

while the average impact of incineration scenario being $44 \%$. Using the EDIP-2003 method (Fig. 5), the obtained results were verified as the average impact of sulphur waste incineration was about $48.3 \%$ with that of sulphur waste landfilling being about $61.7 \%$. The above results showed that the highest environmental impacts were belonged to landfilling by Ecoindicator-99 method, as comparing the two incinerations and landfilling scenarios. These results have been also verified by EDIP-2003 method.

\section{Conclusion}

The main procedure of industrial waste disposal in Tehran oil refinery was transference to the municipal landfill. The landfill with the area of about $13,000,000 \mathrm{~m}^{2}$ has been normally experiencing the trench method for landfilling without surface and groundwater drainage, while suffering from lack of equipment for methane collection. Considering the feasibility of waste incineration in Iran and the outputs of the scenarios presented in this study, the 
incineration was found to be the most efficient scenario. Needless to say, by adding the required facilities to collect the methane gases from landfills in the future, the impacts of main categories such as climate change and global warming will be decreased. Using the sanitary incinerators which require less area and use the energy of the generated heat, the amounts of carcinogens and fossil fuels will be definitely reduced as well.

Acknowledgments The authors wish to extend their sincere gratitude to PRe Consultant Institute who provided the appropriate software and to the Graduate School of the Environment and Energy, Tehran Science and Research Branch, IAU.

\section{References}

Al-Salem SM (2009) Life cycle assessment of municipal solid waste management in the state of Kuwait. Eur J Sci Res 34(3):395-405

Chen HW, Yu RF, Liaw SL, Huang WC (2010) Information policy and management framework for environmental protection organization with ecosystem conception. Int J Sci Tech 7(2):313-326

Curran MA (2006) Environmental life cycle assessment. National risk management research laboratory, office of research and development, U.S. Environmental protection agency, EPA/600/R-92/ 245, McGraw-Hill, New York

Dando DA, Martin DE (2003) A guide for reduction and disposal of waste from oil refineries and marketing installations. CONCAWE/6/03. Brussel

DOE (1995) Oil refineries and bulk storage of crude oil and petroleum products, department of the environment industry profile. Crown copyright

Elshorbagy W, Alkamali A (2005) Solid waste generation from oil and gas industries in United Arab Emirates. J Hazard Mater 120(2):89-99

Epstein PR, Slber J (2002) Oil/life cycle analysis of its health and environmental impacts. The center for health and global environment Publishing Chge Web. http://www.med.harvard.edu/ chge/oil.html
Finnveden G, Johansson J, Lind P, Moberg A (2000) Life cycle assessment of energy from solid waste. fms/2000/R-2/137. FOA Repro, Ursvik

Goedkoop M, Schryver AD, Oele M (2008) Introduction to LCA with Simapro. Product ecology consultants (Pre), Pre/2008/4.2

Guereca LP, Gasso S, Baldasano JM, Guerrero PJ (2006) Life cycle assessment of two biowaste management systems for Barcelona. Resour Conserv Recycl 49(1):32-48

Guinee JB (2002) Handbook on life cycle assessment, operational guide to the ISO standards. Kluwer Academic, Dordrecht

Guinee JB (2011) Life cycle assessment: past, present, and future. Environ Sci Technol 45(1):90-96

ISO 14041 (1998) Environmental management-life cycle assessment: goal and scope definition and inventory analysis. International Organisation for Standardization, Geneva

ISO 14042 (2000) Environmental management-life cycle assessment: life cycle impact assessment. International Organisation for Standardization, Geneva

Levan SL (2007) Life cycle assessment: measuring environmental impact. Int J Life Cycle Ass 12(1):61

Liamsanguan C, Gheewala SH (2007) LCA: a decision support tool for environmental assessment of MSW management systems. J Environ Manage 87(1):132-138

Monavari SM (2009) Management and design of urban solid wastes collection. Jihad Daneshgahi Amir Kabir Industrial Unit, Tehran

Nouri N, Poorhashemi SA, Monavari SM, Dabiri F, Hassani AH (2011) Legal criteria and executive standards of solid waste disposal subjected to solid waste management act. Int $\mathbf{J}$ Environ Res 5(4):971-980

Ortiz M, Raluy RG, Serra L, Uche J (2006) Life cycle assessment of water treatment technologies: wastewater and water-reuse in a small town. J Desalination 204(2):121-131

Tehrani SM, Karbassi AR, Monavari SM, Mirbagheri SA (2010) Role of e-shopping management strategy in urban environment. Int $\mathbf{J}$ Environ Res 4(4):681-690

White N, Clift R, Holmes P, Basson L, Weston N (2011) Streamlined life cycle approaches for use at oil refineries and other large industrial facilities. Ind Eng Chem Res 50(3):1624-1636

Zaman AU (2010) Comparative study of municipal solid waste treatment technologies using life cycle assessment method. Int J Sci Tech 7(2):225-234 